\title{
Hubungan antara Durasi Tidur dengan Asupan Makan, Aktivitas Fisik dan Kejadian Obesitas Pada Mahasiswa Program Studi Pendidikan Dokter UIN Maulana Malik Ibrahim Malang
}

\section{Association of Sleep Duration with Dietary Intake, Physical Activity and Obesity in Medical Student of The Islamic State University Maulana Malik Ibrahim of Malang}

\author{
Ermin Rachmawati ${ }^{1 *}$, Nimas Eka Firdaningrum ${ }^{2}$, Achdiat Agoes ${ }^{3}$ \\ 1 Departemen Fisiologi, Program Studi Pendidikan Dokter, Fakultas Kedokteran dan Ilmu Kesehatan, \\ Universitas Islam Negeri Maulana Malik Ibrahim Malang \\ 2 Mahasiswa Program Studi Pendidikan Dokter, Fakultas Kedokteran dan Ilmu Kesehatan, Universitas Islam \\ Negeri Maulana Malik Ibrahim Malang \\ ${ }^{3}$ Departemen Saraf, Program Studi Pendidikan Dokter, Fakultas Kedokteran dan Ilmu Kesehatan, Universitas \\ Islam Negeri Maulana Malik Ibrahim Malang \\ Jalan Locari, Tlekung, Junrejo, Kota Batu, Jawa Timur Indonesia
}

*Corresponding author

Email: ermin.rachmawati@kedokteran.uin-malanq.ac.id

\begin{tabular}{|c|c|}
\hline & $A b s t r a c t$ \\
\hline $\begin{array}{l}\text { Keyword: } \\
\text { BMI, } \\
\text { Dietary Intake, } \\
\text { Obesity, } \\
\text { Phisycal Activity, } \\
\text { Sleep Duration }\end{array}$ & $\begin{array}{l}\text { Short sleep duration is one of the risk factors in obesity through changes in dietary } \\
\text { behavior and physical activity, which is frequently experienced by medical students. } \\
\text { Meanwhile, Obesity is one of the main nutritional problems in the world including } \\
\text { Indonesia, especially in East Java which is become major risk factor for metabolic } \\
\text { diseases. This study aims to examine the associaton of sleep duration with dietary } \\
\text { intake, physical activity and obesity in medical students of The Islamic State } \\
\text { Univeristy Maulana Malik Ibrahim of Malang. This study used a cross sectional study } \\
\text { design with cluster sampling method. } 78 \text { medical students were participated in this } \\
\text { study. Sleep duration was assessed using Mean Sleep Duration in } 1 \text { Week } \\
\text { questionare, dietary intake was assessed using } 24 \text { Hours Food Recall questionare, } \\
\text { physical activity was assessed using GPAQ (Global Physical Activity Questionnaire) } \\
\text { and obesity was asseesed by BMI (Body Mass Index), which was measured using } \\
\text { SMIC ZT-120 weight and height scale. The data obtained was processed using the } \\
\text { descriptive and inferential statistic using chi-square analysis. Most of the medical } \\
\text { students who participated in this study had poor sleep duration (<6 hours; } 53,8 \%) \text {, } \\
\text { while medical students who had adequate sleep duration (6 hours) were 28,2\% and } \\
\text { good sleep duration (7-9 hours) were } 17,9 \% \text { In Chi-square analysis, sleep duration } \\
\text { had a significant association with dietary intake (p-value = 0,000) and obesity (p- } \\
\text { value = 0,000), while sleep duration had no significant association with physical } \\
\text { activity (p-value = 0,171). This study concluded that poor sleep duration was } \\
\text { associated with obesity through the increase of dietary intake, but not with physical } \\
\text { activity }\end{array}$ \\
\hline
\end{tabular}

Kata kunci :

Body Mass Index,

Asupan Makan,

Kejadian Obesitas,

Aktivitas Fisik,

Durasi Tidur

\section{A B S T R A K}

Durasi tidur yang pendek merupakan masalah yang kerap dihadapi oleh mahasiswa kedokteran. Disisi lain, obesitas merupakan salah satu masalah gizi utama di dunia termasuk Indonesia, dengan salah satu faktor resiko yaitu gangguan fungsi tidur. Penelitian ini bertujuan untuk meneliti hubungan antara durasi tidur dengan asupan makan, aktivitas fisik dan kejadian obesitas pada mahasiswa PSPD UIN Maulana Malik Ibrahim Malang. Penelitian ini merupakan studi cross sectional dengan teknik 
cluster sampling. Sebanyak 78 mahasiswa PSPD UIN Maulana Malik Ibrahim Malang berpartisipasi sebagai responden penelitian ini. Durasi tidur diukur dengan menggunakan kuisioner Rerata Durasi Tidur dalam 1 minggu, asupan makan diukur dengan kuisioner 24 Hours Food Recall, aktivitas fisik diukur dengan kuisioner GPAQ (Global Physical Activity Questionnaire) dan kejadian obesitas dinilai dari BMI (Body Mass Index), BMI diukur dengan menggunakan timbangan berat badan dan tinggi badan SMIC ZT-120. Data yang diperoleh diolah mengggunakan statistik deskriptif dan inferensial, dengan uji analisis chi-square. Dari total 78 responden, didapatkan bahwa sebagian besar mahasiswa memiliki durasi tidur yang buruk $(<6$ jam; $53,8 \%$ ), sedangkan mahasiswa yang memiliki durasi tidur cukup (6 jam) sebesar $28,2 \%$ dan durasi tidur baik (7-9 jam) sebesar 17,9\%. Hasil analisis chi-square menunjukkan bahwa durasi tidur memiliki hubungan yang signifikan dengan asupan makan $(p$-value $=0,000)$ dan kejadian obeistas $(p$-value $=0,000)$, tetapi durasi tidur tidak memiliki hubungan yang signifikan dengan aktivitas fisik $(p$-value $=0,171)$. Durasi tidur yang buruk memiliki hubungan dengan kejadian obesitas melalui asupan makan, tapi tidak dengan aktivitas fisik.

\section{PENDAHULUAN}

Mahasiswa kedokteran merupakan salah satu populasi yang rentan mengalami gangguan kualitas tidur dan durasi tidur, karena mahasiswa kedokteran memiliki beban akademik dan tingkat stres yang lebih tinggi dibandingkan remaja pada umumnya. $^{1}$ Hal ini ditandai dengan kurangnya durasi tidur malam serta seringnya insiden tertidur di siang hari akibat rasa kantuk, yang terkait dengan tingkat stres mahasiswa kedokteran itu sendiri. $^{2}$ Berdasarkan penelitian yang dilakukan oleh Rachmawati et al, telah terbukti bahwa seluruh mahasiswa kedokteran UIN Maulana Malik Ibrahim Malang memiliki kualitas dan durasi tidur yang buruk baik yang mengikuti Program Mahad maupun tidak.,

Gangguan fisiologis tidur merupakan salah satu faktor risiko yang terkait dengan kejadian obesitas. Obesitas merupakan salah satu masalah gizi dengan prevalensi yang tinggi di dunia, dan termasuk di Indonesia. Prevalensi obesitas

dunia terus mengalami peningkatan secara signifkan dalam dua dekade terakhir, yaitu dari $20,3 \%$ pada tahun $1994-1998$, menjadi $35,7 \%$ pada tahun 2009-2010 dan diperkirakan akan terus meningkat menjadi $51 \%$ pada tahun $2030 .{ }^{5}$ Prevalensi obesitas penduduk Indonesia usia $>18$ tahun meningkat tajam dari angka $14,8 \%$ pada tahun 2013 menjadi $21,8 \%$ pada tahun 2018. Berdasarkan data Riskesdas di tahun 2018, Jawa Timur merupakan salah satu provinsi dengan prevalensi obesitas yang cukup tinggi di Indonesia, yaitu sebesar $22,37 \%$, dimana angka tersebut melebihi angka prevalensi obesitas nasional. ${ }^{6,7}$.

Pemerintah Indonesia telah melakukan berbagai macam upaya untuk menanggulangi masalah obesitas, diantaranya adalah dengan dilaksanakanya program GENTAS (Gerakan Nusantara Tekan Angka Obesitas). Akan tetapi program ini belum memberikan hasil yang signifikan, hal ini terbukti dengan belum tercapainya target prevalensi obesitas di Indonesia. Salah satu penyebab belum berhasilnya program penanggulangan obesitas adalah belum efektifnya pengendalian faktor risiko obesitas itu sendiri, termasuk pengelolaan fungsi tidur. $^{8}$

Tidur berdampak pada berat badan seseorang melalui berbagai mekanisme biologis dan perilaku. Durasi tidur yang pendek berperan terhadap kejadian obesitas melalui perilaku yang berhubungan dengan berat badan, yaitu: peningkatan asupan makan dan penurunan aktifitas fisik. ${ }^{9}$ Berbagai penelitian menunjukkan bahwa durasi tidur yang 
pendek memiliki hubungan dengan peningkatan berat badan dan obesitas ${ }^{10,11}$. tetapi juga terdapat penelitian yang menyatakan bahwa tidak terdapat hubungan antara durasi tidur dengan kejadian obesitas. ${ }^{9,12}$. Durasi tidur yang pendek dapat menyebabkan peningkatan rasa lapar, kesempatan untuk makan, serta peningkatan rasa lelah. Peningkatan rasa lapar dan peningkatan kesempatan untuk makan, menyebabkan peningkatan asupan makan seseorang. ${ }^{13}$ Durasi tidur yang kurang (2-4 jam sehari) dapat mengakibatkan penurunan $18 \%$ kadar hormon leptin dan peningkatan $28 \%$ hormon ghrelin yang dapat mengakibatkan peningkatan nafsu makan sebesar 23-24\% . 14 Pada orang dengan durasi tidur yang pendek terjadi peningkatan rasa lelah pada waktu siang hari, hal ini mengakibatkan terjadinya penurunan aktifitas fisik dan jumlah energi yang dikeluarkan. Peningkatan asupan energi yang tidak diimbangi dengan pengeluaran energi yang seimbang dapat menyebabkan obesitas. ${ }^{13}$

Penelitian yang menginvestigasi korelasi antara durasi tidur dengan kejadian obesitas pada mahasiswa PSPD UIN Maulana Malik Ibrahim Malang belum pernah dilakukan sebelumnya. Penelitian ini juga diharapkan dapat memberikan penjelasan terkait mekanisme durasi tidur dalam mempengaruhi kejadian obesitas melalui perantara peningkatan asupan makan dan penurunan aktivitas fisik, sehingga dapat dijadikan sebagai bahan edukasi dan acuan bagi individu usia muda terkait pentingnya menjaga pola hidup sehat, terutama tidur.

\section{METODE PENELITIAN}

\section{Desain Dan Sampel Penelitian}

Penelitian ini merupakan penelitian observasional analitik dengan desain cross sectional (potong lintang). Penelitian ini dilaksanakan di Kampus 3 Fakultas Kedokteran dan Ilmu Kesehatan (FKIK) UIN Maulana Malik Ibrahim Malang pada Bulan Februari-Maret 2020. Populasi dalam penelitian ini adalah mahasiswa semester I-VIII, PSPD UIN Maulana Malik Ibrahim Malang. Pengambilan sampel pada penelitian ini dilakukan dengan dua metode, yaitu: cluster sampling (area sampling) dan simple random sampling. Pertama, sampel penelitian dibagi menjadi dua kelompok, yaitu: mahasiswa PSPD UIN Malang yang tinggal di Ma'had dan Mahasiswa PSPD UIN Malang yang tidak tinggal di Ma'had (Non ma'had) dan kemudian melakukan pengambilan anggota sampel untuk masing-masing kelompok secara acak (random). Jumlah sampel ditetapkan menurut rumus Slovin sebanyak 78 orang. Kriteria inklusi dalam penelitian ini adalah mahasiswa-mahasiswi aktif semester IVIII, PSPD UIN Maulana Malik Ibrahim Malang dan bersedia menjadi responden (informed consent). Kriteria eksklusi dalam penelitian ini adalah: memiliki penyakit genetik familial; menderita hipotiroidisme, hipogonadisme atau penyakit neurologis, seperti; tumor hipofisis; mengalami penyakit ataupun masalah psikologis, seperti: stress dan depresi; mengonsumsi obat steroid, anti kecemasan atau antidepressant; dan sedang melakukan program diet khusus yang memungkinkan terjadinya penurunan atau peningkatan berat badan. Penelitian ini telah mendapat izin dari Komisi Etik Penelitian Kesehatan (KEPK) Fakultas Kedokteran dan Ilmu Kesehatan UIN Maulana Malik Ibrahim Malang yang dibuktikan oleh Lembar Keterangan Kelaikan Etik (Ethical Clearance) No. 010/EC/KEPK-FKIK/2020 tertanggal 15 Januari 2020.

\section{Pengukuran Durasi Tidur}

Prosedur pengukuran durasi tidur pada penelitian ini dilakukan dengan mengisi kuisioner rerata durasi tidur dalam waktu 1 minggu. Jawaban responden kemudian dikelompokan kedalam tiga kategori durasi tidur, yaitu: durasi tidur baik, rata-rata durasi tidur 7-9 jam dalam 1 minggu; durasi tidur cukup, 6 jam dalam 1 
minggu; durasi tidur buruk, $<6$ jam dalam 1 minggu. Pengelompokan kategori durasi tidur pada penelitian ini didasarkan pada rekomendasi durasi tidur untuk dewasa muda (usia 18-25 tahun) menurut National Sleep Foundation $2015 .^{19}$

\section{Pengukuran Asupan Makan}

Asupan makan diukur dengan menggunakan kuisioner survei konsumsi pangan (SKP) 24 Hours Food Recall sebanyak 2 kali dalam 1 minggu $(2 \times 24$ jam). Data asupan makan diklasifikasikan berdasarkan kriteria pemenuhan asupan energy cut off DEPKES 1996, yaitu: asupan makanan kurang, nilai kecukupan energi $<90 \%$ AKG; asupan makan normal, nilai kecukupan energi 90-120\% AKG; asupan makan lebih, nilai kecukupan energi $\geq 120 \% \mathrm{AKG}^{20}$

\section{Pengukuran Aktivitas Fisik}

Aktivitas fisik diukur dengan menggunakan kuisioner GPAQ (Global Physical Activity Questionnaire) yang terdiri 3 domain yaitu aktivitas di tempat kerja, Bepergian ke dan dari berbagai tempat dan aktivitas rekreasi dengan 16 Pertanyaan (P1-16). Data aktivitas fisik diolah menggunakan rumus: Total aktivitas fisik MET-menit/minggu $=[(\mathrm{P} 2 *$ $\mathrm{P} 3 * 8)+(\mathrm{P} 5 * \mathrm{P} 6 * 4)+(\mathrm{P} 8 * \mathrm{P} 9 * 4)+$ $(\mathrm{P} 11 * \mathrm{P} 12 * 8)+(\mathrm{P} 14 * \mathrm{P} 15 * 4)]$. Hasil perhitungan dari formula tersebut kemudian diklasifikasikan berdasarkan konsensus WHO 2010, yaitu: aktivitas fisik rendah, MET <600 MET; aktivitas fisik sedang, 600-3000 MET; aktivitas fisik tinggi, $\geq 3000 \mathrm{MET}^{21}$

\section{Pengukuran Obesitas}

Kejadian obesitas dinilai dari BMI menggunakan rumus berat badan dalam kilogram dibagi dengan kuadrat tinggi badan dalam meter. Body Mass Index (BMI) diukur dengan menggunakan timbangan berat badan dan tinggi badan SMIC ZT-120. Hasil perhitungan BMI kemudian dikonversikan kedalam klasifikasi BMI menurut Asia Pasific
Guidelines: Normal, BMI 18.5-22.9 kg/m Overweight, BMI 22.9-24.9 kg/m²; Obesitas, BMI > $25 \mathrm{~kg} / \mathrm{m}^{2} .{ }^{22}$ Data pada penelitian ini dianalisis dengan menggunakan software SPSS versi 24. Data yang diperoleh diolah mengggunakan statistik deskriptif dan inferensial, dengan uji analisis chi-square $(a=0,05)$.

\section{HASIL DAN PEMBAHASAN}

\section{Hasil Penelitian \\ Karakteristik Responden Penelitian}

Karakteristik responden penelitian tercantum pada Tabel 1. Berdasarkan hasil uji analisi univariat, dari total 78 responden didapatkan sebanyak 34,6\% (27 orang) mahasiswa berjenis kelamin lakilaki dan $65,4 \%$ (51 orang) berjenis kelamin perempuan. Berdasarkan tempat tinggal, didapatkan sebanyak 50\% (39 orang) bertempat tinggal di Mahad dan 50\% (39 orang) bertempat tinggal di luar Mahad (Non Mahad).

\section{Karakteristik Variabel Penelitian}

Hasil penelitian menunjukkan bahwa jumlah responden yang memiliki durasi tidur buruk, cukup, dan baik masingmasing sebanyak 42, 21, dan 14 orang. Responden dengan asupan makan kurang, normal, berlebih sebanyak $6(7,7 \%), 40$ (51,3\%), dan 32 (41\%). Prosentase responden dengan tingkat aktivitas fisik rendah, sedang dan tinggi secara berurutan adalah 56,4\%; 30,8\%; dan $12,8 \%$. Responden dengan kategori BMI normal, oeverweight, dan obesitas adalah $52,6 \%$ (41 orang); $23,1 \%$ (18 orang), dan $24,4 \%$ (19 orang). Hal ini menunjukkan bahwa dari 78 mahasiswa yang berpartisipasi dalam penelitian ini, didapatkan mayoritas mahasiswa memiliki durasi tidur kategori yang buruk $(<6 \mathrm{jam})$; asupan makanan normal (90-120\% AKG); tingkat aktivitas fisik rendah (<600 MET); dan BMI normal $\left(18.5-22.9 \mathrm{~kg} / \mathrm{m}^{2}\right)$ (Tabel 1).

\section{Hubungan antara Tempat Tinggal dengan Durasi Tidur}


Data penelitian menunjukkan bahwa sebagian besar mahasiswa baik yang bertempat tinggal di Ma'had dan Non Mahad sama-sama memiliki durasi tidur yang buruk $(<6$ jam). Berdasarkan hasil analisis, didapatkan $p$ value (nilai probabilitas) sebesar 0,287. Hal ini menunjukkan bahwa tidak terdapat hubungan yang signifikan antara tempat tinggal dengan durasi tidur mahasiswa PSPD UIN Maulana Malik Ibrahim (Tabel 2).

\section{Hubungan antara Durasi Tidur dengan Asupan Makan}

Hasil penelitian ini menunjukkan bahwa sebagian besar mahasiswa yang durasi tidurnya buruk $(<6$ jam $)$ memiliki asupan makanan yang tergolong lebih $(33,3 \%)$, sementara sebagian besar mahasiswa yang durasi tidurnya cukup (6 jam) dan baik (7-9 jam) memiliki asupan makanan yang normal (16,7\%; 15,4\%). Berdasarkan hasil analisis, didapatkan $p$ value (nilai probabilitas) sebesar 0,000. Hal ini menunjukkan bahwa terdapat hubungan yang signifikan antara durasi tidur dengan asupan makanan mahasiswa
PSPD UIN Maulana Malik Ibrahim Malang ditunjukkan dalam Tabel 3.

\section{Hubungan antara Durasi Tidur dengan Aktivitas Fisik}

Analisis hubungan antara durasi tidur dengan aktivitas fisik dapat dilihat pada Tabel 4. Pada penelitian ini dapat disimpulkan bahwa tidak terdapat hubungan yang signifikan antara durasi tidur dengan aktifitas fisik mahasiswa PSPD UIN Maulana Malik Ibrahim $(\mathrm{p}=0,171)$.

\section{Hubungan antara Durasi Tidur dengan \\ Kejadian Obesitas ditinjau dari parameter BMI (Body Mass Index)}

Pada penelitian ini didapatkan bahwa sebagian besar mahasiswa yang durasi tidurnya buruk mengalami obesitas $(21,8 \%)$. Menariknya, mahasiswa yang durasi tidurnya cukup dan baik memiliki BMI normal (23,1\%; 17,9\%). Hasil analisis dengan Chi Square menunjukkan bahwa terdapat hubungan yang signifikan antara durasi tidur dengan kejadian obesitas pada mahasiswa PSPD UIN Maulana Malik Ibrahim Malang $(\mathrm{p}=0,000<0,05)$.

\section{Tabel 1.Distribusi Frekuensi Karakteristik Sosiodemografik dan Parameter Penelitian}

\begin{tabular}{lcc}
\multicolumn{3}{c}{ Responden } \\
\hline \multicolumn{1}{c}{ Parameter } & Frekuensi & Persentase \\
\hline Jenis Kelamin & & \\
Laki-laki & 27 & $34.6 \%$ \\
$\begin{array}{l}\text { Perempuan } \\
\text { Tempat Tinggal }\end{array}$ & 51 & $65.4 \%$ \\
$\begin{array}{l}\text { Non Mahad } \\
\text { Mahad } \\
\text { Durasi tidur }\end{array}$ & 39 & $50 \%$ \\
Buruk & 39 & $50 \%$ \\
Cukup & & \\
Baik & 42 & $53.8 \%$ \\
Asupan Makan & 22 & $28.2 \%$ \\
Kurang & 14 & $17.9 \%$ \\
Normal & & \\
Lebih & 6 & $7.7 \%$ \\
Kategori aktivitas fisik & 40 & $51.3 \%$ \\
Rendah & 32 & $41.0 \%$ \\
Sedang & & \\
Tinggi & 44 & $56.4 \%$ \\
Kategori BMI & 24 & $30.8 \%$ \\
Normal & 10 & $12.8 \%$ \\
Overweight & & \\
Obesitas & 41 & $52.6 \%$ \\
\hline
\end{tabular}


Mahasiswa bertempat tiggal di Mahad, Ket: mahasiswa semester I-IV; Mahasiswa bertempat tinggal di Non Mahad, mahasiswa semester V-VIII. Kategori durasi tidur diklasifikasikan berdasarkan kriteria rekomendasi durasi tidur untuk dewasa muda (usia 18-25 tahun) menurut National Sleep Foundation (2015); Durasi tidur buruk, <6 jam; Durasi tidur cukup, 6 jam; Durasi tidur baik, 7-9 jam. Kategori asupan makan diklasifikasikan berdasarkan kriteria pemenuhan asupan energi cut off DEPKES 1996 (KEMENKES 2018); Asupan makan kurang, <90\% AKG; Asupan makan normal, 90-120\% AKG; Asupan makan lebih, >120\% AKG. Kategori aktivitas fisik diklasifikasikan berdasarkan konsensus WHO (2010) tentang kriteria tingkat aktivitas fisik dalam Global Physical Activity Qustionnaire Analysis Guide; Aktivitas fisik rendah, MET <600 MET; Aktivitas fisik sedang, 600-3000 MET; Aktivitas fisik tinggi, $\geq 3000$ MET. Kategori BMI (Body Mass Index) diklasifikasikan berdasarkan konsensus WHO (2000) tentang kriteria BMI dalam Asia Pacific Guidelinse; Normal, BMI 18.5-22.9 kg/m2; Overweight, BMI 22.9-24.9 kg/m2; Obesitas, BMI > 25 kg/m2.

Tabel 2. Hubungan antara Tempat Tinggal dengan Durasi Tidur

\begin{tabular}{|c|c|c|c|c|c|c|c|c|c|}
\hline \multirow{3}{*}{ Tempat Tinggal } & \multicolumn{6}{|c|}{ Durasi Tidur } & \multirow{2}{*}{\multicolumn{2}{|c|}{ Jumlah }} & \multirow{3}{*}{$\mathbf{p}$} \\
\hline & \multicolumn{2}{|c|}{ Buruk } & \multicolumn{2}{|c|}{ Cukup } & \multicolumn{2}{|c|}{ Baik } & & & \\
\hline & $\mathbf{n}$ & $\%$ & $\mathbf{n}$ & $\%$ & $\mathbf{n}$ & $\%$ & $\mathbf{n}$ & $\%$ & \\
\hline Mahad & 18 & 23.1 & 14 & 17.9 & 7 & 9.0 & 39 & 50.0 & \\
\hline Non Mahad & 24 & 30.8 & 8 & 10.3 & 7 & 9.0 & 39 & 50.0 & 0.287 \\
\hline Total & 42 & 53.8 & 22 & 28.2 & 14 & 18.0 & 78 & 100 & \\
\hline
\end{tabular}

Mahasiswa bertempat tiggal di Mahad, mahasiswa semester I-IV; Mahasiswa bertempat tinggal di Non Mahad, mahasiswa semester V-VIII; Durasi tidur buruk, <6 jam; Durasi tidur cukup, 6 jam; Durasi tidur baik, 7-9 jam.

Tabel 3. Hubungan antara Durasi Tidur dengan Asupan Makan

\begin{tabular}{|c|c|c|c|c|c|c|c|c|c|}
\hline \multirow{3}{*}{ Durasi Tidur } & \multicolumn{6}{|c|}{ Asupan Makanan } & \multirow{2}{*}{\multicolumn{2}{|c|}{ Jumlah }} & \multirow{3}{*}{ P Value } \\
\hline & \multicolumn{2}{|c|}{ Kurang } & \multicolumn{2}{|c|}{ Normal } & \multicolumn{2}{|c|}{ Lebih } & & & \\
\hline & $\mathbf{n}$ & $\%$ & $\mathbf{n}$ & $\%$ & $\mathbf{n}$ & $\%$ & $\mathbf{n}$ & $\%$ & \\
\hline Buruk & 1 & $1.3 \%$ & 15 & $19.2 \%$ & 26 & $33.3 \%$ & 42 & $53.8 \%$ & \multirow{4}{*}{$0.000 * *$} \\
\hline Cukup & 3 & $3.8 \%$ & 13 & $16.7 \%$ & 6 & $7.7 \%$ & 22 & $28.2 \%$ & \\
\hline Baik & 2 & $2.6 \%$ & 12 & $15.4 \%$ & 0 & $0 \%$ & 14 & $17.9 \%$ & \\
\hline Total & 6 & $7.7 \%$ & 40 & $51.3 \%$ & 32 & $41.0 \%$ & 78 & $100 \%$ & \\
\hline
\end{tabular}

Durasi tidur buruk, <6 jam; Durasi tidur cukup, 6 jam; Durasi tidur baik, 7-9 jam; Asupan Makan kurang, < 90\% AKG; Asupan makan normal, 90-120\% AKG; Asupan makan lebih,>120\% AKG.

Tabel 4. Hubungan antara Durasi Tidur dengan Aktivitas Fisik

\begin{tabular}{|c|c|c|c|c|c|c|c|c|c|}
\hline \multirow{3}{*}{ Durasi Tidur } & \multicolumn{6}{|c|}{ Aktivitas Fisik } & \multirow{2}{*}{\multicolumn{2}{|c|}{ Jumlah }} & \multirow{3}{*}{ P Value } \\
\hline & \multicolumn{2}{|c|}{ Rendah } & \multicolumn{2}{|c|}{ Sedang } & \multicolumn{2}{|c|}{ Tinggi } & & & \\
\hline & $\mathbf{n}$ & $\%$ & $\mathbf{n}$ & $\%$ & $\mathbf{n}$ & $\%$ & $\mathbf{n}$ & $\%$ & \\
\hline Buruk & 28 & $35.9 \%$ & 11 & $14.1 \%$ & 3 & $3.8 \%$ & 42 & $53.8 \%$ & \multirow{4}{*}{0.171} \\
\hline Cukup & 11 & $14.1 \%$ & 8 & $10.3 \%$ & 3 & $3.8 \%$ & 22 & $28.2 \%$ & \\
\hline Baik & 5 & $6.4 \%$ & 5 & $6.4 \%$ & 4 & $5.1 \%$ & 14 & $17.9 \%$ & \\
\hline Total & 44 & $56.4 \%$ & 24 & $30.8 \%$ & 10 & $12.8 \%$ & 78 & $100 \%$ & \\
\hline
\end{tabular}

Durasi tidur buruk, <6 jam; Durasi tidur cukup, 6 jam; Durasi tidur baik, 7-9 jam; Aktivitas fisik rendah, < 600 MET; Aktivitas fisik sedang, 600-3000 MET; Aktivitas fisik tinggi, $\geq 3000$ MET.

Tabel 5. Hubungan antara Durasi Tidur dengan Kejadian Obesitas ditinjau dari parameter BMI

\begin{tabular}{|c|c|c|c|c|c|c|c|c|c|}
\hline \multirow{3}{*}{ Durasi Tidur } & \multicolumn{6}{|c|}{ BMI } & \multirow{2}{*}{\multicolumn{2}{|c|}{ Jumlah }} & \multirow{3}{*}{ P Value } \\
\hline & \multicolumn{2}{|c|}{ Normal } & \multirow{2}{*}{\multicolumn{2}{|c|}{ Overweight }} & \multicolumn{2}{|c|}{ Obesitas } & & & \\
\hline & $\mathbf{n}$ & $\%$ & $\mathbf{n}$ & & $\mathbf{n}$ & $\%$ & $\mathbf{n}$ & $\%$ & \\
\hline Buruk & 9 & $11.5 \%$ & 16 & $20.5 \%$ & 17 & $21.8 \%$ & 42 & $53.8 \%$ & \multirow{4}{*}{$0.000 * *$} \\
\hline Cukup & 18 & $23.1 \%$ & 2 & $2.6 \%$ & 2 & $2.6 \%$ & 22 & $28.2 \%$ & \\
\hline Baik & 14 & $17.9 \%$ & 0 & $0.0 \%$ & 0 & $0.0 \%$ & 14 & $17.9 \%$ & \\
\hline Total & 41 & $52.6 \%$ & 18 & $23.1 \%$ & 19 & $24.4 \%$ & 78 & $100 \%$ & \\
\hline
\end{tabular}

Durasi tidur buruk, <6 jam; Durasi tidur cukup, 6 jam; Durasi tidur baik, 7-9 jam; BMI, Body Mass Index; Normal, BMI 19.5$22.9 \mathrm{~kg} / \mathrm{m}^{2}$; Overweight, BMI 22.9-24.9 kg/m²; Obesitas, BMI > $25 \mathrm{~kg} / \mathrm{m}^{2}$ 
Analisis hubungan antara durasi tidur dengan kejadian obesitas ditunjukkan pada Tabel 5

\section{PEMBAHASAN}

Tidur merupakan kebutuhan dasar manusia yang memiliki peranan penting dalam proses pertumbuhan, penyimpanan energi, restorasi dan homeostasis tubuh. ${ }^{15}$ Tidur yang sehat terdiri atas beberapa indikator, yaitu: durasi tidur yang memadai, kualitas tidur yang baik, waktu tidur yang tepat, dan tidak adanya gangguan tidur. ${ }^{16}$ Durasi tidur merupakan indikator utama dari komponen tidur yang memiliki peranan penting terhadap kesehatan seseorang. Mahasiswa kedokteran merupakan suatu populasi yang rentan mengalami gangguan kulitas dan durasi tidur. Hal ini disebabkan karena mahasiswa kedokteran memiliki beban akademik dan tingkat stres yang lebih tinggi dibandingkan remaja pada umumnya. ${ }^{17}$ Pada penelitian ini didapatkan hasil bahwa mayoritas mahasiswa PSPD UIN Maulana Malik Ibrahim Malang memiliki durasi tidur yang buruk (<6jam) $(53,8 \%)$.

Tempat tinggal merupakan salah satu faktor yang berkorelasi dengan durasi tidur mahasiswa kedokteran. Mahasiswa kedokteran di Cina yang tinggal dilingkungan asrama memiliki durasi tidur yang lebih singkat dibandingkan dengan yang tidak tinggal di asrama. $^{18}$ Hasil penelitian ini memiliki perbedaan dengan hasil penelitian di Cina, dimana mayoritas mahasiswa PSPD UIN Maulana Malik Ibrahim Malang baik yang tinggal di Ma'had ataupun tidak tinggal di Ma'had (Non ma'had) sama-sama memiliki durasi tidur yang buruk dan sesuai dengan penelitian sebelumnya yang dilakukan oleh Rachmawati dan Riskiyana. ${ }^{4}$ Hasil ini kemungkinan disebabkan oleh perbedaan beban akademik dari tiap tingkatan semester mahasiswa kedokteran, dimana durasi tidur yang buruk memiliki hubungan yang signifikan dengan semakin tingginya tingkatan tahun studi mahasiswa kedokteran. ${ }^{19,20 .}$ Berdasarkan uraian diatas, dapat disimpulkan bahwa meskipun mahasiswa yang tidak tinggal di Ma'had (Non Ma'had) tidak memiliki tambahan jadwal aktivitas Ma'had, beban akademik yang mereka miliki lebih tinggi dibandingkan dengan mahasiswa yang tinggal di Ma'had.

Durasi tidur yang singkat (kurang) memiliki hubungan terhadap kejadian berbagai macam penyakit kronis, salah satunya obesitas. ${ }^{21}$ Rangan et al menyebutkan terdapat korelasi negatif antara durasi tidur di malam hari dengan $\triangle$ BMI z-score $(\beta=-0,090, \mathrm{P}=0,046) .{ }^{22}$ Sebuah studi kohort prospektif juga menunjukkan bahwa durasi tidur yang pendek ( $<7$ jam) memiliki pengaruh yang signifikan terhadap risiko untuk mengalami overweight (BMI $>25 \mathrm{~kg} / \mathrm{m}^{2}$; $\mathrm{OR}=1,42 ; 95 \% \mathrm{CI}=1,06-1,90 ; p=0,020)$ dan obesitas (BMI $>30 \mathrm{~kg} / \mathrm{m}^{2} ; \mathrm{OR}=1,40$; $95 \% \mathrm{CI}=1,02-1,94 ; p=0,047){ }^{23}$

Durasi tidur yang pendek berperan terhadap kejadian obesitas melalui perilaku yang berhubungan dengan berat badan, yaitu: peningkatan asupan makan (perilaku makan berlebihan) dan penurunan aktifitas fisik. ${ }^{13,24}$. Hasil penelitian ini mendukung konsep tersebut. Hasil penelitian ini menunjukkan bahwa durasi tidur memiliki hubungan yang signifikan dengan kejadan obesitas ( $p$ value $=0,000)$, dimana sebagian besar mahasiswa dengan durasi tidur yang buruk (<6 jam) memiliki BMI yang termasuk kedalam kategori obesitas (BMI > 25 $\mathrm{kg} / \mathrm{m}^{2}$ ). Hasil penelitian ini juga menunjukkan bahwa urasi tidur secara signifikan berkorelasi dengan asupan makan $(p$ value $=0,000)$. Hal ini sejalan dengan penelitian yang dilakukan oleh Patterson et al, disebutkan bahwa orang dewasa dengan durasi tidur yang panjang memiliki asupan energi (kcal/hari) yang lebih sedikit dibandingkan dengan orang dewasa dengan durasi tidur pendek $(\leq 6$ jam) (durasi tidur 7 jam, $-50 \mathrm{kcal} / \mathrm{hari} ; 8$ jam, $\quad-41 \mathrm{kcal} / \mathrm{hari} ; \geq 9$ jam, -187 
kcal/hari). ${ }^{25}$ Sebuah studi cross sectional juga menunjukkan bahwa durasi tidur yang pendek berhubungan dengan risiko peningkatan asupan makan harian sebesar $\geq 1987 \mathrm{~kJ} \quad(475 \mathrm{kkal}){ }^{26}$ Mekanisme fisiologi yang menyebabkan peningkatan asupan makan pada saat malam hari adalah terjadinya penurunan kadar hormon leptin dan peningkatan kadar hormon ghrelin yang mengakibatkan peningkatan nafsu makan dan rasa lapar, utamanya terhadap peningkatan asupan makanan tinggi kalori, karbohidrat dan lemak. ${ }^{27,28,29,30,31,32,33 .}$

Hubungan antara durasi tidur dengan aktivitas fisik telah banyak diteliti pada penelitian-penelitian sebelumnya. Durasi tidur yang pendek berpengaruh terhadap terjadinya penurunan maximal oksigen uptake, kelelahan dan rasa kantuk yang berlebih di siang hari sehingga terjadi penurunan aktivitas fisik. ${ }^{9,34}$ Aktivitas fisik memiliki korelasi positif dengan massa lemak bebas (fat free mass) sehingga mengurangi kejadian obesitas. ${ }^{35}$ Hasil analisis chi-square didapatkan bahwa durasi tidur tidak memiliki hubungan yang signifikan dengan aktivitas fisik ( $p$ value $=0,171)$. Hasil penelitian ini sejalan dengan HELENA (Healthy Lifestyle in Europe by Nutrition in Adolescence) Study (2011), dari penelitian remaja (usia 12,5-17,5 tahun) $(\mathrm{n}=3311)$ yang berasal dari 10 negara di Eropa tidak menunjukkan hasil adanya hubungan yang signifikan antara durasi tidur dengan aktivitas fisik. 9,36,38,39. Shlisky et al, menyatakan bahwa faktor utama yang mendasari hubungan antara durasi tidur dengan kejadian obesitas adalah intake energi, bukan aktivitas fisik. ${ }^{37}$

Terdapat beberapa limitasi dalam penelitian ini diantaranya adalah desain dan instrument yang digunakan. Penelitian lanjutan diharapkan dapat menggunakan desain penelitian prospektif dengan jumlah sampel yang lebih besar, variasi metode pengukuran parameter yang melibatkan analisa marker biomolekuler untuk mendapatkan hasil penelitian yang lebih valid.

\section{KESIMPULAN DAN SARAN}

Penelitian ini menunjukkan bahwa terdapat hubungan antara durasi tidur yang pendek terhadap peningkatan kejadian obesitas, melalui peningkatan asupan makan, namun tidak aktivitas fisik pada mahasiswa PSPD UIN Maulana Malik Ibrahim Malang.

\section{DAFTAR PUSTAKA}

1. Brick, C.A., Seely, D.L., Palermo, T.M., 2010. Association between Sleep Hygiene and Sleep Quality in Medical Students. Behav Sleep Med, 8(2):113-121.

2. Sweileh, W.M., Ali, I.A., Sawalha, A.F., Abu-Taha, A.S., Zyoud, S.H., Al-Jabi, S.W., 2011. Sleep Habits and Sleep Problems among Palestinian Students. Child Adolesc Ment Health, 5(1): 1-25.

3. Rachmawati, E., Farid Wafi, M., Resmi Melani, I., 2017. Correlation Between Academic Stress, Sleep Quality, Circadian Misalignment, Cortisol Concentration and Heart Rate Value at the First Year Medical Student at the State Islamic University Maulana Malik Ibrahim of Malang:, Dalam: Proceedings of Surabaya International Physiology Seminar. Presented at the Surabaya International Physiology Seminar, SCITEPRESS - Science and Technology Publications, Jawa Timur, Indonesia, 84-90.

4. Rachmawati, Ermin dan Riskiyana. 2018. Pengaruh Kekurangan Tidur terhadap Tekanan Sistolik dan Konsentrasi Nitric Oxide pada Mahasiswa Kedokteran Wilayah Malang. Unpublished.

5. Finkelstein, E.A., Khavjou, O.A., Thompson, H., Trogdon, J.P., Pan, L., Sherry, B., Dietz, W., 2012. Obesity and Severe Obesity Forecasts through 2030. Am J Prev Med, 42(6): 563-570. 
6. KEMENKES RI. 2018. Hasil Utama Riset Kesehatan Dasar 2018. Jakarta: Badan Penelitian dan Pengembangan Kesehatan Kementerian Kesehatan Republik Indonesia.

7. WHO. 2016. World Health Statistics 2015 Part II: Global Health Indicators. Geneva: World Health Organization.

8. KEMENKES RI. 2017. Panduan Pelaksanaan Gerakan Nusantara Tekan Angka Obesitas (GENTAS). Jakarta: Direktorat Pencegahan dan Pengendalian Penyakit Tidak Menular Kementrian Kesehatan Republik Indonesia.

9. Hayes, J.F., Balantekin, K.N., Altman, M., Wilfley, D.E., Taylor, C.B., Williams, J., 2018. Sleep Patterns and Patterns and Quality are Associated with Severity of Obesity and WeightRelated Behaviors in Adolescents with Overweight and Obesity. Childhood Obesity, 14(1): 11-17.

10. Marfuah, D., Hadi, H., Huriyati, E., 2016. Durasi dan Kualitas Tidur Hubungannya dengan Obesitas pada Anak Sekolah Dasar di Kota Yogyakarta dan Kabupaten Bantul. Jurnal Gizi dan Dietik Indonesia, 1(2): 93-101.

11. Chung, K.F., Kan, K.K.K., Yeung, W.F., 2013. Sleep Duration, SleepWake Schedule Regularity and Body Weight in Hong Kong Chinese Adolescents. Biol Rhythm Res, 44:169-179.

12. Adamo, K.B., Wilson, S., Belanger, K., Chaput, J.P., 2014. Later Bedtime is Associated with Greater Daily Energy Intake and Screen Time in Obese Adolescents Independent of Sleep Duration. Dalam: Vash PD. Complexity of Adolescent Obesity: Causes, Correlates, and Consequences. Canada: Apple Academic Press Oakville.

13. Zimberg, I.Z., Dâmaso, A., Del Re, M., Carneiro, A.M., Sá Souza, H., Lira, F.S., Tufik, S., Mello, M.T.,
2012. Short sleep duration and obesity: mechanisms and future perspectives: SLEEP AND OBESITY. Cell Biochem. Funct. 30, 524-529.

14. Ramadhaniah, R., Julia, M., Huriyati, E., 2014. Durasi tidur, Asupan energi dan Aktivitas fisik dengan Kejadian Obesitas pada Tenaga Kesehatan Puskesmas. Jurnal Gizi Klinik Indonesia, 11(2): 85-96.

15. Karen, J.M., Robert, K., Hal, J., Richard, B., 2014. Nelson Ilmu Kesehatan Anak Esensial. Jakarta: ELSEVIER.

16. Chaput, J.P., Dutil, C., SampasaKanyinga, H., 2018. Sleeping Hours: What is The Ideal Number and How does Age Impact This. Dovepress Journal: Nature and Science of Sleep, 10: 421-430.

17. Brick, C.A., Seely, D.L., Palermo, T.M., 2010. Association between Sleep Hygiene and Sleep Quality in Medical Students. Behav Sleep Med, 8(2):113-121.

18. Feng, G., Chen, J., Yang, X. 2005. Study on The Status and Quality of Sleep-Related Influencing Factors in Medical College Students. Zhonghua Liu Xing Bing Xue Za Zhi, 26: 328331.

19. Suen, L.K.P., Ellis Hon, K.L., Tam, W.W.S. 2008. Association between Sleep Behavior and Sleep-Related Factors among University Students in Hong Kong. Chronobiology International, 25(5): 760-775.

20. Alaswad, W., Renad, A., Fawzy, S., 2017. Differene of Sleeping Patterns and Habit between First and Third Year Medical Students. Internatonal Journal of Medical and Health Research, 3(12): 16-21.

21. Chaput, J.P., Dutil, C., SampasaKanyinga, H., 2018. Sleeping Hours: What is The Ideal Number and How does Age Impact This. Dovepress Journal: Nature and Science of Sleep, 10: 421-430. 
22. Del Pozo-Cruz, B., Gant, N., Del Pozo-Cruz, J., Maddison, R. 2017. Relationships Between Sleep Duration, Physical Activity and Body Mass Index in Young New Zealanders: An Isotemporal Substitution Analysis. Plos One, 12(9): 1-12.

23. Maugeri, A., Medina-Inojosa, J., Kunzova, S., Agodi, A., Barchitta, M., Sochor, O., Lopez-Jimenez, F., Geda, Y., Vinciguerra, M., 2018. Sleep Duration and Excessive Daytime Sleepiness Are Associated with Obesity Independent of Diet and Physical Activity. Nutrients 10 (1219): 1-13.

24. Hagenauer MH dan Lee TM. 2013. Adolescent Sleep Patterns in Humans and

Laboratory Animals. Horm Behav 64:270-279.

25. Patterson, R.E., Emond, J.A., Natarajan, L., Wesseling-Perry, K., Kolonel, L.N., Jardack, P., AncoliIsrael, S., Arab, L., 2014. Short Sleep Duration is Associated with Higher Energy Intake and Expenditure among African-American and Non-Hispanic White Adults. J. Nutr. 144: 461-466.

26. Weiss, A., Xu, F., Storfer-Isser, A., Thomas, A., Ievers-Landis, C.E., Redline, S. 2010. The Association of Sleep Duration with Adolescent's Fat and Carbohydrate Consumption. Sleep. 33(9): 1201-1209.

27. Sutanto, C. M., Wang, M. X., Tan, D., Kim, J. E. 2020. Association of Sleep Quality and Macronutrient Distribution: A Systematic Review and Meta-Regression. MDPI.J. Nutrients. 12(126): 1-21.

28. Spiegel, K., Esra, T., Plamen, P., Eve, V.C. 2004. Brief Communication: Sleep Curtailment in Healthy Young Men Is Associated With Decreased Leptin Levels, Elevated Ghrelin Levels, And Increased Hunger And Appetite. Ann Intern Med, 141: 846850.
29. Spaeth, A.M., Dinges, D.F., Goel, N. 2013. Effects of Experimental Sleep Restriction on Weight Gain, Caloric Intake, and Meal Timing in Healthy Adults. Sleep. 36:981-990.

30. Silva, M.-R.G., Silva, H.-H., Paiva, T. 2018. Reduced or Escessive Sleep Duration is Associated to The Consumption of High Caloric Food in Young Roller-Hockey Players. Clinical Nutrition. 37: S231.

31. Dashti, H.S., Scheer, F.A., Jacques, P.F., Lamon-Fava, S., Ordovás, J.M., 2015. Short Sleep Duration and Dietary Intake: Epidemiologic Evidence, Mechanisms and Health Implications. Adv Nutr American Society for Nutrition, 6: 648-659.

32. Carneiro, B.T.; Araujo, J.F. 2009. The food-entrainable oscillator: A network of interconnected brain structures entrained by humoral signals? Chronobiol. Int. 26:1273-1289.

33. Bel, S., Michels, N., De Vriendt, T., Patterson, E., Cuenca-García, M., Diethelm, K., Gutin, B., Grammatikaki, E., Manios, Y., Leclercq, C., Ortega, F.B., Moreno, L.A., Gottrand, F., Gonzalez-Gross, M., Widhalm, K., Kafatos, A., Garaulet, M., Molnar, D., Kaufman, J.-M., Gilbert, C.C., Hallström, L., Sjöström, M., Marcos, A., De Henauw, S., Huybrechts, I. 2013. Association Between Self-Reported Sleep Duration And Dietary Quality In European Adolescents. British Journal of Nutrition, 110: 949-959.

34. Štefan, L., Vrgoč, G., Rupčić, T., Sporiš, G., Sekulić, D. 2018. Sleep Duration and Sleep Quality Are Associated with Physical Activity in Elderly People Living in Nursing Homes. Int. J. Environ. Res. Public Health 15, 2512: 19.

35. Riso, E.M., Kull, M., Mooses, K., Jürimäe, J. 2018. Physical Activity, Sedentary Time and Sleep Duration: Associations with Body Composition in 10-12-year-old Estonian School 
Children. BMC Public Health. 18(496): 1-7.

36. Garaulet, M., Ortega, F.B., Ruiz, J.R., Rey-Lo'pez, J.P., Be'ghin, L., Manios, Y., Cuenca-Garci'a, M., Plada, M., Diethelm, K., Kafatos, A., Molna'r, D., Al-Tahan, J., Moreno, L.A., 2011. Short Sleep Duration is Associated with Increased Obesity Markers in European Adolescents: Effect of Physical Activity and Dietary Habits. The HELENA Study. International Journal of Obesity. 35(10):1308-1317.

37. Shlisky, J.D., Hartman, T.J., KrisEtherton, P.M., Rogers, C.J., Sharkey, N.A., Nickols-Richardson, S.M. 2012. Partial Sleep Deprivation and Energy Balance in Adults: An Emerging Issue for Consideration by Dietetics Practitioners. J. Acad. Nutr. Diet, 112(11): 1785-1797.

38. Klingenberg, L., Sjodin, A., Holmback, U., Astrup, A., Chaput, J.P. 2012. Short Sleep Duration and Its Association with Energy Metabolism. Obes. Rev, 13(7): 565577.

39. Kobel, S., Wartha, O., Dreyhaupt, J., Kettner, S., Steinacker, J.M. 2019. Cross-Sectional Associations of Objectively Assessed Sleep Duration With Physical Activity, BMI And Television Viewing In German Primary School Children. $B M C$ Pediatr. 19, 54: 1-10. 